\title{
Characterization of Curtoviruses Associated with Curly Top Disease of Tomato in California and Monitoring for These Viruses in Beet Leafhoppers
}

\author{
Li-Fang Chen, Department of Plant Pathology, University of California, Davis, One Shields Ave., Davis 95616; \\ Kelly Brannigan and Rod Clark, California Department of Food and Agriculture, Curly Top Virus Control Pro- \\ gram, 2895 N. Larkin Ave., Suite A, Fresno 93727; and Robert L. Gilbertson, Department of Plant Pathology, Uni- \\ versity of California, Davis, One Shields Ave., Davis 95616
}

\begin{abstract}
Chen, L.-F., Brannigan, K., Clark, R., and Gilbertson, R. L. 2010. Characterization of curtoviruses associated with curly top disease of tomato in California and monitoring for these viruses in beet leafhoppers. Plant Dis. 94:99-108.

Curly top disease is caused by a complex of curtoviruses (family Geminiviridae), and it continues to plague tomato production in California. To better understand the etiology of curly top of tomatoes in California, polymerase chain reaction (PCR)-based methods were developed and used to characterize the curtoviruses involved, and to monitor for these viruses in the beet leafhopper vector, Circulifer tenellus. From 2002 to 2008, 86 processing and fresh market tomato fields in the Central Valley of California were surveyed for the incidence of curly top symptoms. Representative samples with curly top symptoms were collected from the surveyed fields, as well as from another 24 fields. The incidence of curly top symptoms in most fields ranged from trace $(<1 \%)$ to low ( 1 to $5 \%)$; however, in 2002,2003 , and 2008 , some fields had medium (5 to $20 \%)$ or high $(>20 \%)$ incidences. PCR with general and species-specific primers was used to establish that the predominant species associated with tomato curly top disease were Beet mild curly top virus (BMCTV) and, to a lesser extent, Beet severe curly top virus (BSCTV). The incidence, relative amount, and species of curly top virus in leafhoppers, collected at monthly intervals by the California Department of Food and Agriculture (CDFA) personnel during 2003 to 2008, was also determined. The predominant species detected were BMCTV and BSCTV. The highest incidences of curly top in tomato fields were associated with high populations of leafhoppers (e.g., in 2003 when populations were two times greater than average) having high incidences and levels of curly top virus early in the growing seasons (e.g., March to May 2003 and 2008). Detection of curly top virus in leafhoppers early in the growing season was consistent with acquisition of virus from reservoir hosts in the foothills. However, continued detection of curly top virus in leafhoppers throughout the growing season and development of curly top in late-planted fresh market tomatoes were consistent with the presence of inoculum sources (e.g., weeds or crop plants) in the agricultural areas of the Central Valley. Geographical locations or "hotspots" having higher proportions of curly top virus-positive leafhoppers were identified, which may reveal areas having high concentrations of curly top virus reservoir hosts. The application of these molecular tools has provided new insight into curly top of tomato in California, and may lead to improved curly top management.
\end{abstract}

Geminiviruses are a large family of plant viruses that have circular singlestranded DNA genomes encapsidated in small $(18 \times 30 \mathrm{~nm})$ twinned-icosahedral virions $(25,26)$. Viruses in the family Geminiviridae are divided into four genera (Mastrevirus, Curtovirus, Topocuvirus, and Begomovirus) based on the characteristics of virus genome, host range, and type of insect vector $(14,25,26)$. The genus Curtovirus contains viruses that cause curly top disease of various vegetable and field crops (3). Curtoviruses have a monopartite genome $(\sim 3.0 \mathrm{~kb})$, infect dicotyledonous

Corresponding author: R. L. Gilbertson

E-mail: rlgilbertson@ucdavis.edu

Accepted for publication 21 September 2009.

doi:10.1094/PDIS-94-1-0099

(C) 2010 The American Phytopathological Society
United States, including California. Although not as important in recent years, the disease can still cause significant losses. For example, in 2001, hundreds of acres of processing tomatoes in the Central Valley of California were afflicted with curly top, and losses were estimated to be in the millions of dollars. In 2002, common bean production in the Columbia basin in Washington State suffered significant losses due to curly top (22). Thus, although the occurrence of curly top is sporadic, it has the potential to cause significant economic losses. Moreover, because the factors that lead to severe curly top outbreaks are not well understood, it is difficult to predict the relative disease incidence and severity in a given year.

Early studies provided evidence of genetic diversity among curly top viruses based upon differences in host range and symptoms induced in certain host plants (3). Subsequent molecular studies confirmed genetic diversity among curly top viruses, and revealed that three distinct curtovirus species are associated with curly top in the western United States: Beet curly top virus (BCTV, the type strain and previously the $\mathrm{Cal} / \operatorname{Logan}$ strain of BCTV), Beet mild curly top virus (BMCTV, previously the Worland strain of BCTV), and Beet severe curly top virus (BSCTV, previously the CFH strain of BCTV) (6,33,34,36,37,39). Additional curtovirus species include Horseradish curly top virus (20), Spinach curly top virus (2), and Pepper yellow dwarf virus (21).

Curtoviruses are vectored by the beet leafhopper, Circulifer tenellus (Baker). In the western United States, curly top virus transmission to crop plants occurs as leafhoppers undergo an annual migration (3). In California, adult leafhoppers overwinter on perennial weeds (e.g., Russian thistle [Salsola tragus L.], perennial pepperweed [Lepidium sp.], and saltbrush [Atriplex sp.]) in the foothills of the coastal range on the west side of the Central Valley, and lay eggs on annual weeds (e.g., filaree [Erodium spp.] and buckhorn plantain [Plantago lanceolata L.]) that have germinated following winter rains $(9,30)$. Nymphs are thought to acquire curly top viruses from infected perennial and annual weeds in the foothills, and when these hosts dry out in mid- to late spring, 
viruliferous adult leafhoppers migrate to the agricultural areas of the Central Valley, where they transmit viruses to crops or weeds (e.g., mustards [Brassica sp.], broadleaf plantain $[P$. major L.], London rocket [Sisymbrium irio L.], lambsquarter [Chenopodium sp. L.], redroot pigweeds [Amaranthus retroflexus L.], and Russian thistle). During the growing season, leafhoppers undergo several generations $(17,32)$, migrate between weeds and crops, and continue to spread curly top virus. In the late fall, adult leafhoppers migrate back to the foothills for overwintering $(23,29)$.

Dot blot hybridization with a BSCTV probe was used to detect curly top virus infection in crops (e.g., common bean, melon, pepper, sugar beet, and tomato) and weeds from 14 families in California (9). Most curly top virus-infected crops had disease symptoms and high virus titers, whereas most curly top virus-infected weeds were symptomless and had lower virus titers and infection rates. Infected crops and weeds were detected in the cultivated areas throughout the growing season, suggesting that the virus persists in the valley and may not have to be reintroduced every year with migrating leafhoppers (9).

Consistent long-term control of curly top has been difficult due to the complex epidemiology of the disease (i.e., the wide host range of the viruses and the beet leafhopper, and the unpredictable annual migratory behavior of the vector). The use of highly resistant common bean varieties and moderately resistant sugar beet varieties has reduced the impact of curly top in these crops $(3,22,40)$. However, curly top virus-resistant bell pepper and processing tomato varieties are not currently available. Because plants tend to be most susceptible to curly top virus at early stages of growth, planting time can be adjusted to allow maximum plant growth before leafhoppers migrate to the valley floor $(3,41)$. In tomato, increased seeding rates can reduce curly top losses, as uninfected plants will compensate for losses from infected plants. In California, a statewide Curly Top Virus Control Program (CTVCP) was initiated in 1943 with the goal of managing curly top in crops grown in the Central Valley through an aerial spray program targeting leafhoppers overwintering in the foothills. The CTVCP has continued these annual insecticide sprays; however, this program is becoming more difficult to sustain due to high annual operational costs, the difficulty of spraying the vast areas where leafhoppers overwinter, and concerns about environmental impact.

Although curly top has been a problem in California tomatoes since the 1920s, relatively little is known of the nature of the curly top viruses causing the disease, or when and where tomatoes become infected. There is also no reliable indicator for the annual incidence of the disease and/or whether the disease will cause economic losses in a given growing season. The application of the polymerase chain reaction (PCR) and DNA sequencing has greatly facilitated the characterization and identification of geminiviruses, including curtoviruses $(8,16,31,39)$, and has allowed for detection of viral DNA in insect vectors (27). In the present study, PCR methods were used to identify and characterize curtoviruses associated with curly top of processing and fresh market tomatoes in the Central Valley of California, and to assess whether monitoring of these viruses in leafhoppers could be used as a predictor of curly top in the field.

\section{MATERIALS AND METHODS}

Surveys for the incidence of curly top symptoms in California tomato fields. Surveys for the incidence of curly top symptoms in tomato fields, and sampling of tomato plants with representative curly top symptoms, were conducted from 2002 to 2008 in the Central Valley of California. Surveys for incidence of curly top symptoms were conducted in fresh market (Merced County only) and processing tomato fields in Fresno, Kern (2003 only), and Merced counties. Here, an entire field or a large portion of a field was walked in a zig-zag pattern, and plants were examined for curly top symptoms, e.g., stunted growth and leaves showing up-curling, light green to yellow discoloration and vein purpling. In each field, at least 100 plants were examined. Disease incidence in these fields was then classified as none, trace $(<1 \%)$, low (1 to $5 \%)$, medium (5 to $20 \%$ ), or high (>20\%).

Samples of tomatoes with curly top symptoms were collected during the surveys for confirmation of curly top virus infection and to determine the virus species associated with the disease. Other samples with curly top virus symptoms were received from farm advisors in Fresno, Merced, Monterey, Stanislaus, and Yolo counties.

DNA extraction and detection of curly top virus by PCR. Total genomic DNA was extracted from leaf tissue by the Dellaporta method as previously described $(11,24)$. The resulting DNA pellet was suspended in $200 \mu \mathrm{l}$ of sterile distilled water, and $1 \mu \mathrm{l}$ of this extract was further diluted 1:100 in sterile distilled water for use in the PCR. One microliter of the diluted extract was used in the PCR with the general curly top virus primer pair (BGv377 and BGc1509) as previously described (6,31). This primer pair directs the amplification of an $\sim 1.1-\mathrm{kb}$ fragment from genomic DNA of BCTV, BMCTV, and BSCTV (6).

For samples that tested positive for curly top virus infection with the general primer pair, another primer pair (BMCTVv2195 [5'-CTAAAAGGCCGCGCAG-3'] and
BMCTVc514 [5'-CCTCAGTAGCTTCTT CACTTCC- $3^{\prime}$ ]) was used in the PCR to direct the amplification of an $\sim 1.2-\mathrm{kb}$ curly top virus DNA fragment, which includes the more divergent intergenic region (IR) and $\mathrm{C} 1 / \mathrm{C} 4$ open reading frame (ORF) sequences (referred to as the divergent curly top virus fragment). The PCR parameters used with this primer pair were the following: an initial denaturing step at $94^{\circ} \mathrm{C}$ for $5 \mathrm{~min}$ followed by $94^{\circ} \mathrm{C}$ for 1 min, $58^{\circ} \mathrm{C}$ for $2 \mathrm{~min}$, and $72^{\circ} \mathrm{C}$ for $2 \mathrm{~min}$ for 30 cycles, with a final extension step at $72^{\circ} \mathrm{C}$ for $10 \mathrm{~min}$. PCR products were analyzed by electrophoresis in $0.8 \%$ agarose gels in $1 \times$ TAE buffer $(40 \mathrm{mM}$ Tris and 1 $\mathrm{mM}$ EDTA). Gels were stained with ethidium bromide (EtBr), and DNA was visualized by UV light. For selected samples collected in 2002 and 2003, the PCRamplified $\sim 1.2 \mathrm{~kb}$ divergent curly top virus fragments were purified with the QIAquick PCR Purification Kit (Qiagen, Germantown, MD) and sequenced to identify the curly top virus species associated with that sample. Beginning in 2004, PCR with curly top virus species-specific primers (described in the following section) was used for species identification.

Generation and evaluation of BCTV-, BMCTV-, and BSCTV-specific primers. Curtovirus species-specific primers were designed by aligning selected regions of the BCTV, BMCTV, and BSCTV genomes and identifying divergent sequences (6). A species-specific virion-sense primer was designed for each species, and these were paired with a common complementarysense primer designed from a conserved sequence in the overlapping sequences of the V2/V3 ORFs. The PCR parameters and specificity of the species-specific primer pairs were evaluated in gradient PCR tests with DNA extracts prepared from Nicotiana benthamiana or tomato plants infected with BCTV, BMCTV, or BSCTV. PCR tests with these primer pairs also were performed with DNA extracts prepared from viruliferous and nonviruliferous beet leafhoppers.

Beet leafhopper collection. Beet leafhopper populations were estimated and collected by CTVCP personnel as part of the annual monitoring program. In these surveys, vegetation in the surveyed areas is sampled with sweep nets to estimate beet leafhopper populations in order to identify areas to spray. Comparison of beet leafhopper populations in 2003 to 2007 were based on estimations made by CTVCP personnel. Beet leafhoppers collected during these samplings were placed into vials with $70 \%$ ethanol and sent to UC Davis for processing. From 2003 to 2008, beet leafhoppers were received at approximately monthly intervals beginning in JanuaryMarch and ending in SeptemberNovember. The number of locations from which beet leafhoppers were collected each month varied (up to 32 locations) and 
depended on weather conditions and insect populations. Most of the locations where beet leafhoppers were collected were in the foothills of the coastal mountains or in agricultural areas in and around the "westside areas" of the Central Valley in Fresno, Kings, and Merced counties. Beet leafhopper samples were also received from Imperial, Kern, and Riverside counties.

The geographical coordinates of each location where beet leafhoppers were collected were recorded, and for 2004 to 2008, the host plant(s) from which the beet leafhoppers were collected was recorded. Maps showing locations where beet leafhoppers were collected were generated by the Geographic Coordination System (GCS) ArcGIS 9.2 using North America Albers Equal Area Conic Projection (ESRI, Redlands, CA).

Extraction of DNA from beet leafhoppers and detection of curly top viruses by PCR. Beet leafhoppers were placed into Eppendorf tubes (up to 15 insects), and total genomic DNA was extracted as described by Soto and Gilbertson (31). Suspensions were extracted twice with phenol/chloroform, and DNA was recovered by ethanol precipitation. The DNA was suspended in $20 \mu \mathrm{l}$ of sterile distilled water and then further diluted based on the number of leafhoppers used to make the extract (e.g., 1:1 for a single beet leafhopper up to $1: 15$ for 15 beet leafhoppers). One microliter of the diluted DNA was used in the PCR. The primers and PCR parameters were the same as those used with DNA extracts from leaf tissues.

\section{RESULTS}

Curly top survey in California tomato fields in 2002 and 2003. In 2002, curly top surveys were performed in tomato fields in Fresno County, and tomato samples with curly top symptoms were collected from the surveyed fields and also received from Stanislaus County (Table 1). The overall incidence of curly top symptoms in the eight tomato fields surveyed in Fresno County was medium to high (10 to $25 \%$ ), and a total of 45 samples were collected from these fields. Using PCR and the general primer pair, curly top virus infection was detected in most of these samples (89\%), including samples from all eight fields (Table 1). Curly top virus infection was also detected in samples from three of six fields in Stanislaus County. A second PCR was performed with representative curly top virus-positive samples from each field to amplify the divergent curly top virus fragment for species identification. Sequence analyses of these fragments revealed that BMCTV was associated with curly top in Stanislaus County, whereas BMCTV and BSCTV were associated with curly top in Fresno County (Table 1).

In 2003, the overall incidence of curly top symptoms in tomato fields was high in Kern County (e.g., $>50 \%$ in the five fields surveyed), whereas the incidence was lower $(<1$ to $5 \%)$ in the five fields surveyed in Fresno County. A total of 165 samples with curly top symptoms were collected or received from Fresno, Kern, Stanislaus, and Yolo counties; most samples were from tomatoes, but 6 were from peppers (from one field) and 5 were from sugar beets (from one field). Samples from Fresno and Kern counties were $>70 \%$ positive for curly top virus infection based on PCR with the general primer pair (Table 1). In the case of Yolo County, only 50\% of the 45 samples from 12 fields were curly top virus positive. This lower level of detection was attributed to a substantial number of samples that did not have typical curly top symptoms.

The second PCR was performed with representative curly top virus-positive samples, and sequence analyses of the divergent curly top virus fragment indicated that BMCTV was the prevalent species. BSCTV was also associated with the disease in Fresno, Kern, and Yolo counties (Table 1), especially in Fresno County, where it was detected in $50 \%$ of the samples (Table 1). The samples from pepper and sugar beet plants collected in Fresno County were all positive for curly top virus infection, and BSCTV was detected in all of these samples.

Development of curly top virus species-specific primer pairs and their application in curly top surveys in 2004 to 2008. During the course of this study, species-specific primers were developed for the PCR-based detection of BCTV, BMCTV, and BSCTV. Here, the IR, and $\mathrm{C} 1$ and $\mathrm{C} 4 \mathrm{ORF}$ sequences of BCTV, BMCTV, and BSCTV were aligned, and divergent regions were identified (6; data not shown). Virus-specific virion-sense primers for BCTV, BMCTV, and BSCTV were designed based on divergent sequences identified in the central region of the $\mathrm{C} 1 \mathrm{ORF}$, the $5^{\prime}$ ends of the $\mathrm{C} 1 \mathrm{ORF} / \mathrm{IR}$,

Table 1. Detection and identification of curly top viruses in samples from tomato plants with curly top symptoms collected from fresh market and processing tomato fields in the Central Valley of California in 2002 to $2008^{\text {a }}$

\begin{tabular}{|c|c|c|c|c|c|c|}
\hline \multirow[b]{2}{*}{ Year } & \multirow[b]{2}{*}{ Location } & \multirow{2}{*}{$\begin{array}{l}\text { No. positive/ } \\
\text { total fields }\end{array}$} & \multirow{2}{*}{$\begin{array}{c}\text { PCR positive/ } \\
\text { total samples }(\%)\end{array}$} & \multicolumn{3}{|c|}{ Species identification $(\%)^{\mathrm{d}}$} \\
\hline & & & & BCTV & BMCTV & BSCTV \\
\hline \multirow[t]{2}{*}{2002} & Fresno & $8 / 8$ & $40 / 45(89)^{*}$ & 0 & 38 & 62 \\
\hline & Stanislaus & $3 / 6$ & $12 / 30(40)$ & 0 & 100 & 0 \\
\hline \multirow[t]{4}{*}{2003} & Fresno & $5 / 5$ & $56 / 78(72)^{*}$ & 0 & 50 & 50 \\
\hline & Kern & $5 / 5$ & $24 / 29(83)^{*}$ & 0 & 75 & 25 \\
\hline & Stanislaus & $1 / 1$ & $2 / 2(100)$ & 0 & 100 & 0 \\
\hline & Yolo & $8 / 12$ & $24 / 45(53)$ & 0 & 80 & 20 \\
\hline \multirow[t]{5}{*}{2004} & Fresno & $3 / 3$ & $5 / 12(42)^{*}$ & 0 & 20 & 80 \\
\hline & Merced & $12 / 12$ & $71 / 75(95) *$ & 0 & 86 & 35 \\
\hline & Monterey & $1 / 1$ & $3 / 3(100)$ & 0 & 100 & 0 \\
\hline & Stanislaus & $1 / 1$ & $2 / 2(100)$ & 0 & 100 & 0 \\
\hline & Yolo & $0 / 1$ & $0 / 10(0)$ & 0 & 0 & 0 \\
\hline \multirow[t]{2}{*}{2005} & Fresno & $3 / 4$ & $14 / 29(48)^{*}$ & 0 & 36 & 64 \\
\hline & Merced & $6 / 9$ & $21 / 26(81)^{*}$ & 0 & 90 & 10 \\
\hline \multirow[t]{2}{*}{2006} & Fresno & $5 / 7$ & $30 / 41(73)^{*}$ & 0 & 40 & 87 \\
\hline & Merced & $9 / 9$ & $59 / 66(89) *$ & 0 & 36 & 80 \\
\hline \multirow[t]{3}{*}{2008} & Fresno & $12 / 15$ & 78/107 (73)* & 0 & 60 & 56 \\
\hline & Merced & $7 / 9$ & $43 / 61(70)^{*}$ & 0 & 44 & 60 \\
\hline & Monterey & $2 / 2$ & $7 / 8(88)$ & 0 & 71 & 43 \\
\hline
\end{tabular}

${ }^{\text {a }}$ Curly top symptoms were not found in 2007 surveys, nor were samples with curly top symptoms received.

${ }^{b}$ Number of fields with curly top virus-positive plants detected by polymerase chain reaction (PCR) with the general curly top virus primer pair/total number of fields in which plants with curly top symptoms were collected (either during the curly top incidence surveys or by collaborators).

${ }^{c}$ Number of samples positive for curly top virus infection. Based on PCR detection of viral DNA with the general primer pair/total samples tested. Asterisks indicate samples collected as part of the curly top incidence surveys.

${ }^{\mathrm{d}}$ Percentage of curly top virus-positive tomato samples in which Beet curly top virus (BCTV), Beet mild curly top virus (BMCTV), and/or Beet severe curly top virus (BSCTV) were detected. In 2002 and 2003, species identification was determined by sequence analysis of a portion of the viral DNA fragment amplified by PCR with primer pair BMCTVv2195/BMCTVc514; whereas in 2004 to 2008, species were identified by PCR with species-specific primer pairs. 
and an overlapping region of the $\mathrm{C} 1 / \mathrm{C} 4$ ORFs, respectively (Fig. 1, Table 2). When these primers were individually paired with the common complementary-sense primer (BGc396) designed from the conserved V2/V3 ORF sequence, DNA fragments of 965,506 , and 720 bp were amplified from extracts of $N$. benthamiana leaves infected with BCTV, BMCTV, or BSCTV, respectively (Fig. 1). No fragments were amplified from DNA extracts prepared from uninfected $N$. benthamiana leaves. Furthermore, the BCTV-, BMCTV-, and BSCTV-specific primer pairs did not direct the amplification of DNA fragments from extracts of leaves infected with the other curly top virus species (Fig. 1). Similar results were obtained with DNA extracts prepared from beet leafhoppers; the expected-size fragment was amplified from DNA extracts of beet leafhoppers carrying the corresponding curly top virus species, whereas no fragment was amplified from extracts of non-viruliferous beet leafhoppers or beet leafhoppers carrying the other curly top virus species (data not shown). These results established that these primer pairs are species-specific, and thus they were used to identify the curly top virus species in samples collected in curly top surveys conducted in 2004 to 2008.

Table 2. Curtovirus species-specific primers designed for polymerase chain reaction (PCR) detection of Beet curly top virus (BCTV), Beet mild curly top virus (BMCTV), and Beet severe curly top virus (BSCTV)

\begin{tabular}{llc}
\hline Primer $^{\mathbf{a}}$ & \multicolumn{1}{c}{ Sequence } & ${\text { Size of amplified } \text { fragment }^{\mathbf{b}}}^{{ }^{\prime}}$ \\
\hline BCTVv2557 & 5'-GCTTGGTCAAGAGAAGT-3' & $965 \mathrm{bp}$ \\
BSCTVv2688 & 5'-GCTGGTACTTCGATGTTG-3' & $720 \mathrm{bp}$ \\
BMCTVv2825 & 5'-TGATCGAGGCATGGTT-3' & $506 \mathrm{bp}$ \\
\hline
\end{tabular}

${ }^{\mathrm{a}} \mathrm{v}=$ virion-sense, and number indicates position of corresponding $5^{\prime}$ nucleotide in complete nucleotide sequence of indicated curtovirus species.

b Size of DNA fragment amplified when each specific primer is paired with a general complementarysense primer (BGc396 [5'-CAACTGGTCGATACTGCTAG-3']) which anneals within the V2/V3 gene.
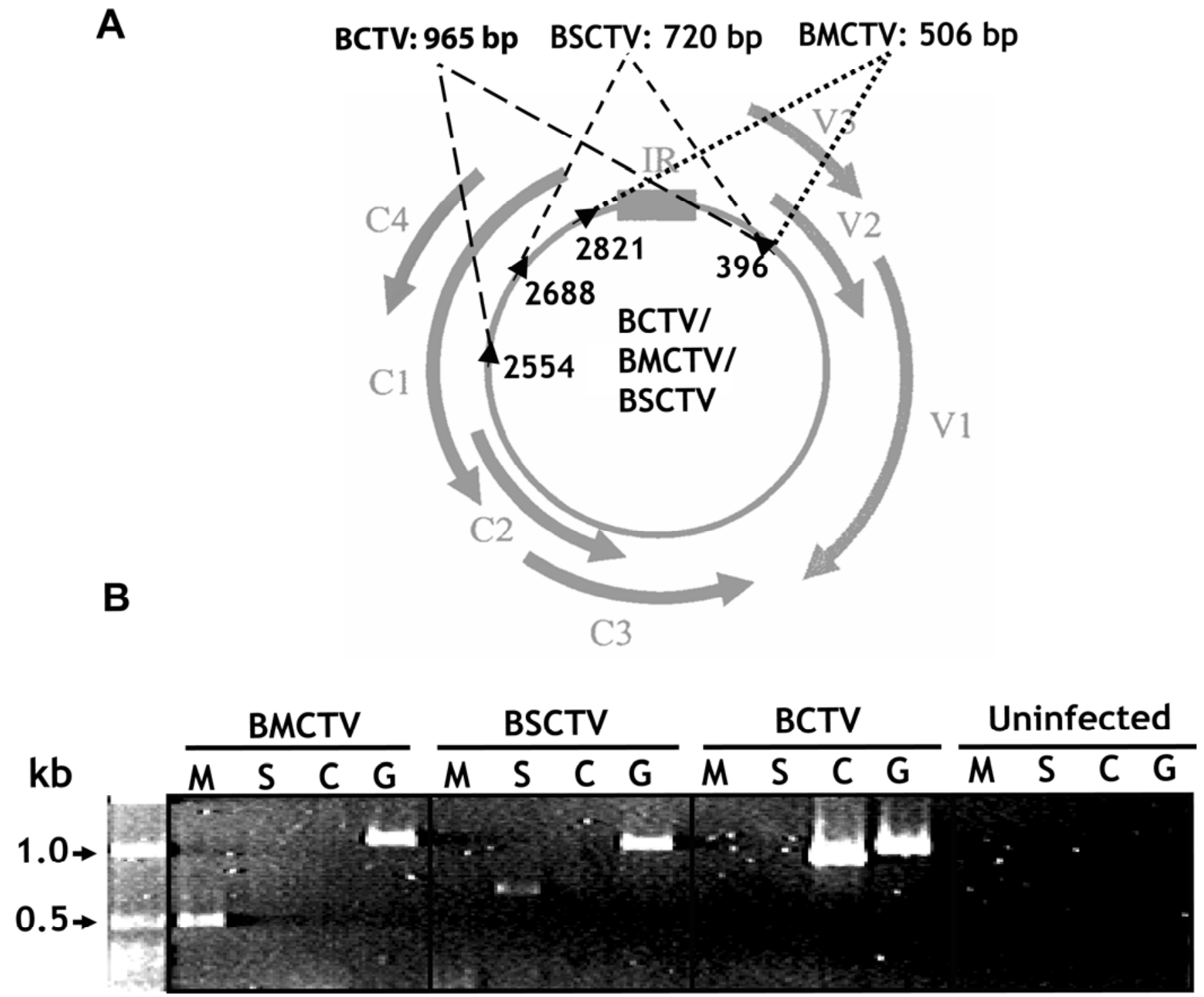

Fig. 1. Detection of Beet curly top virus (BCTV), Beet mild curly top virus (BMCTV), and Beet severe curly top virus (BSCTV) by polymerase chain reaction (PCR) with species-specific primers. A, Diagrammatic illustration showing the location of the BCTV, BMCTV, and BSCTV specific primers (Table 2) on a generalized curtovirus genome map. When paired with the general primer (BGc396), the BCTV primer directs the amplification of an $\sim 1-\mathrm{kb}$ fragment from BCTV genomic DNA, the BMCTV primer directs the amplification of an $\sim 0.5-\mathrm{kb}$ fragment from BMCTV genomic DNA, and the BSCTV primer directs the amplification of an $\sim 0.7-\mathrm{kb}$ fragment from BSCTV genomic DNA. B, Ethidium bromide-stained gel showing BCTV, BMCTV, and BSCTV fragments amplified by PCR with the species-specific primers from total genomic DNA extracted from leaf tissues of uninfected Nicotiana benthamiana plants (uninfected) or plants infected with BCTV, BMCTV, or BSCTV. Abbreviations: C, BCTV-specific primer pair; G, general curly top virus primer pair (BGv377/BGc1509); M, BMCTV-specific primer pair; and S, BSCTV-specific primer pair. 
In 2004, the overall incidence of curly top in tomato fields in Fresno (3 fields) and Merced (12 fields) counties was at trace levels $(<1 \%)$. A total of 75 samples with curly top symptoms were collected from the surveyed fields in Merced County, and curly top virus infection was detected in most of these samples $(95 \%)$ and in samples from each field (Table 1). It is interesting to note that two of the fields in which curly top virus-infected plants were detected were late-planted (in July) fresh market tomato fields. PCR with the curly top virus species-specific primer pairs revealed BMCTV and BSCTV infection in 86 and $35 \%$ of the curly top viruspositive samples, respectively, with mixed infection in $21 \%$ of these samples. In Fresno County, a total of 12 samples were collected from the surveyed fields. Curly top virus infection was detected in only 5 samples, with positive samples from each field. PCR with the curly top virus speciesspecific primer pairs revealed more infection with BSCTV than with BMCTV in these samples (Table 1). Samples with curly top symptoms received from Monterey and Stanislaus counties were all infected with BMCTV; whereas no curly top virus infection was detected in samples from Yolo County, which did not show typical curly top symptoms (Table 1 ).

Surveys conducted in 2005 revealed trace to low incidences $(<1$ to $3 \%)$ of curly top symptoms in tomato fields in Fresno (4 fields) and Merced ( 9 fields) counties. A total of 26 samples with curly top symptoms were collected from the surveyed fields in Merced County. Curly top virus infection was detected in most of these samples $(81 \%)$ and from 6 of 9 fields. Three fields in which curly top virusinfected plants were detected were lateplanted fresh market fields. BMCTV was detected in most of the curly top viruspositive samples $(90 \%)$, whereas BSCTV was detected in the other samples (Table 1). There were no mixed infections. In Fresno County, a total of 29 samples with curly top symptoms were collected from the surveyed fields, and curly top virus infection was detected in 14 of these samples from 3 fields. BMCTV and BSCTV were detected in 36 and $64 \%$ of the curly top virus-positive samples, respectively. Samples from sugar beet plants with curly top symptoms were infected with BSCTV (data not shown).

In 2006, surveys in tomato fields in Fresno ( 7 fields) and Merced (9 fields) counties revealed trace to low incidences $(<1 \%)$ of curly top symptoms. A total of 107 samples were collected from the surveyed fields in both counties. Curly top virus infection was detected in most of these samples (83\%), with positive samples from 14 of 16 fields. Three fields in which curly top virus-infected plants were detected were late-planted fresh market fields in Merced County. Interestingly,
BSCTV was the most prevalent curly top virus species detected in samples from Merced and Fresno counties in 2006, although BMCTV also was detected (Table 1). Mixed infections were detected in 27 and $16 \%$ of the samples from Fresno and Merced counties, respectively.

Surveys in 2008 revealed trace to low incidences $(\sim 1 \%)$ of curly top symptoms in 9 surveyed tomato fields in Merced County. A total of 61 samples were collected from these fields, and curly top virus infection was detected in most of these samples $(70 \%)$, with positive samples from 7 fields. Four fields in which curly top virus-infected plants were detected were late-planted fresh market fields. BMCTV and BSCTV were detected in 44 and $60 \%$ of the curly top viruspositive samples, respectively, with mixed infection in $5 \%$ of the samples. In Fresno County, surveys conducted in 15 tomato fields revealed low to medium incidences (1 to $10 \%$ ) of curly top symptoms. A fresh market tomato field planted near the foothills had an incidence of $>50 \%$. A total of 107 samples were collected from these fields, and curly top virus infection was detected in 78 samples (73\%), with positive samples from 12 of 15 fields. BMCTV and BSCTV were detected in 60 and $56 \%$ of the curly top virus-positive samples, respectively, with mixed infection in $16 \%$ of these samples (Table 1).

Additional samples of squash, pepper, and spinach plants with curly top symptoms were collected in Fresno County in 2008. All of the pepper samples were infected with BSCTV, spinach samples were infected with both BMCTV and BSCTV, and squash samples were infected with BMCTV (data not shown).

Monitoring for curly top virus in beet leafhoppers in the Central Valley. Curly top virus was detected in beet leafhoppers by PCR with the general primer pair as previously described (30). This method allows for the detection of the virus in a single insect. Beet leafhoppers collected by CTVCP personnel were tested for curly top virus by PCR during the 2003 to 2008 growing seasons (January-March to September-November). In addition to indicating the percentage of beet leafhopper samples in which virus was detected, the relative amount of virus in the beet leafhoppers (i.e., virus titer) was estimated based on the intensity of the PCRamplified curly top virus DNA fragments (indicated as weak, medium, or strong). The results of these tests are summarized in Figure 2.

In 2003, beet leafhopper populations for the entire year and spring were 2.0 and 2.3 times greater, respectively, than the mean populations for 2003 to 2007. In 2003, curly top virus was detected in $>70 \%$ of beet leafhopper samples early in the season (e.g., March to May) and in $100 \%$ of the samples collected in the summer months
(July and August). The number of beet leafhoppers in which virus was detected decreased in the fall, although virus was still detected in $63 \%$ of the beet leafhopper samples collected in November (Fig. 2). The relative amount of virus detected in beet leafhoppers was highest early in the season and declined by fall. These results indicated that adult beet leafhoppers migrating into the valley in the spring were carrying a high viral load, presumably acquired during feeding on infected annual and/or perennial weeds in the foothill areas.

In 2004, fewer beet leafhoppers were collected early in the season compared with 2003 (equivalent to the overall mean populations for 2003 to 2007), and curly top virus was detected in a smaller proportion of samples, especially those collected in February and March. The proportion of beet leafhopper samples in which virus was detected increased during the growing season, peaked in July, and then declined into the fall, with the exception of beet leafhoppers collected in September (Fig. 2). In 2005, beet leafhopper populations for the entire year and spring were 0.5 and 0.25 , respectively, of the overall mean populations for 2003 to 2007 . PCR results for beet leafhoppers collected in 2005 were similar to those for beet leafhoppers collected in 2004. Thus, the proportion of beet leafhoppers having curly top virus was initially low, peaked in July, and then declined in the fall (Fig. 2). Overall, the relative virus titer in beet leafhoppers was lower in 2004 and 2005 compared with 2003.

In 2006, beet leafhopper populations for the entire year and spring were equivalent to the overall mean populations for 2003 to 2007. Curly top virus was detected in all of the beet leafhopper samples collected in January and in $\sim 50 \%$ of those collected in February and March. No insects were collected in June and July because of low populations. Although curly top virus was detected in all beet leafhopper samples collected in the fall (August and September), the beet leafhopper population and viral titer were low (Fig. 2). In 2007, beet leafhopper populations for the entire year and spring were only 0.5 and 0.3 , respectively, of the overall mean populations for 2003 to 2007. Curly top virus was detected in all of the beet leafhopper samples collected in February, dropped to $25 \%$ of samples in March, and then increased to $100 \%$ of samples collected in the summer and fall. Although curly top virus was detected in all beet leafhopper samples collected in the summer and fall (except August), the viral titer in these insects was low (Fig. 2).

In 2008, curly top virus was detected in a high proportion of the beet leafhoppers collected in March to May ( $>50 \%$ ), and the viral titer in these insects was relatively high. The beet leafhopper population de- 
clined in the summer, and no insects were collected in June and August, although virus was detected in all beet leafhoppers collected in July (Fig. 2). Curly top virus was detected in beet leafhoppers collected in the fall, and viral titer was relatively high, especially for insects collected in September.
Identification of curly top virus species in beet leafhoppers. The curly top virus species carried by beet leafhoppers was determined by sequencing the divergent curly top virus fragment (2003) or by PCR with the species-specific primers (2004 to 2008). Of the 6 curly top viruspositive beet leafhopper samples examined in 2003, BMCTV and BSCTV were each detected in 3 samples (data not shown). For beet leafhoppers collected in 2004 to 2008, results of PCR with the speciesspecific primer pairs are shown in Figure 3. BMCTV was the prevalent curly top virus detected in beet leafhoppers over these five growing seasons, although

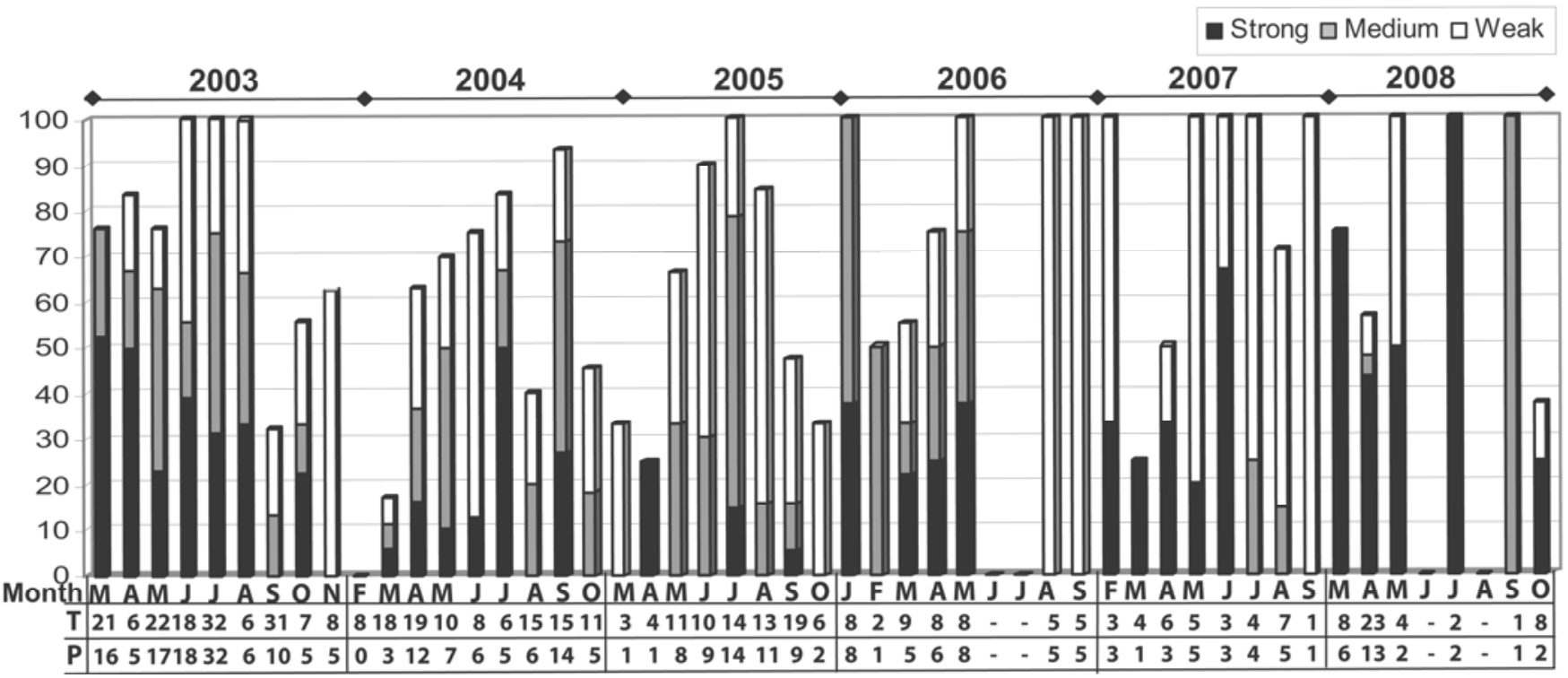

Fig. 2. Percentage of beet leafhopper samples (Circulifer tenellus) in which curly top virus was detected by polymerase chain reaction (PCR) with a general curly top virus primer pair (BGv377/BGc1509) during 2003 to 2008, and the relative intensity (strong, medium, and weak) of the PCR-amplified DNA fragment visualized in an ethidium bromide-stained gel. Abbreviations: P, number of locations where curly top virus-positive leafhoppers were detected; and T, total number of locations where leafhoppers were collected. In June and July 2006 and June and August 2007, leafhoppers were not collected because populations were too low.

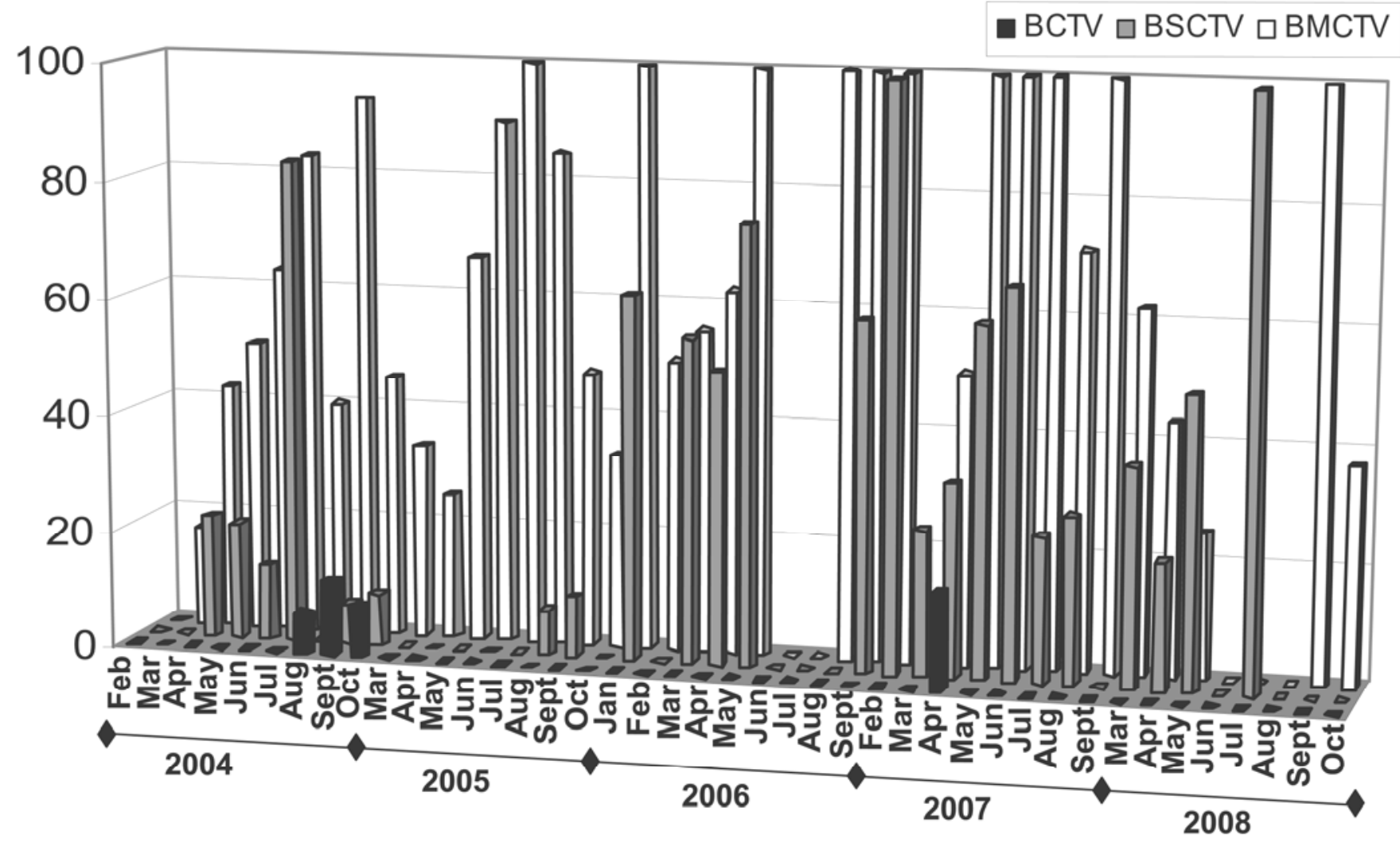

Fig. 3. Percentage of curtovirus-positive beet leafhoppers (Circulifer tenellus) in which Beet curly top virus (BCTV), Beet mild curly top virus (BMCTV), and Beet severe curly top virus (BSCTV) were detected by polymerase chain reaction (PCR) with species-specific primer pairs during 2004 to 2008. 
BSCTV was also commonly detected, especially in 2004 and 2006 to 2008 (Fig. 3).

Interestingly, BCTV was detected in a small number of beet leafhopper samples collected late in the growing season of 2004 and in the spring of 2007. To further confirm this, the PCR-amplified fragments from the BCTV-positive samples in 2004 and 2007 were sequenced. Sequence analyses revealed that these fragments (4 samples for 2004 and 1 sample for 2007) had 94 to $98 \%$ identity with the equivalent sequence of BCTV. Moreover, as this fragment represents a relatively divergent region of the viral genome, these results are consistent with bona fide detection of BCTV. However, the level of BCTV in these beet leafhoppers was low, based upon the weak intensity of the PCRamplified fragment.

Mixtures of curly top viruses were also detected in some beet leafhopper samples, with $\sim 9 \%$ of insects having BMCTV/ BSCTV and $<1 \%$ having BMCTV/BCTV or BCTV/BMCTV/BSCTV. Together, these results showed that BMCTV, and to a lesser extent BSCTV, were the prevalent curtoviruses carried by beet leafhoppers during this period (Fig. 3).

Mapping locations of beet leafhoppers collected in the Central Valley and correlation with PCR detection of curly top virus. The geographical coordinates of the locations where beet leafhoppers were collected during the 2003 to 2008 growing seasons were recorded, which allowed for the identification of the locations of curly top virus-positive beet leafhoppers on maps generated by the GCS (Fig. 4). In 2003, beet leafhoppers were collected from the western parts of Fresno and Kings counties. Clusters or hotspots of curly top virus-positive leafhoppers with high viral titers were in central and southwestern Fresno County and western Kings County (Fig. 4A). There also were some clusters of curly top virusnegative beet leafhoppers, including southern Fresno County and northwestern and southwestern Kings County.

In 2004, areas with the highest proportion of curly top virus-positive beet leaf-
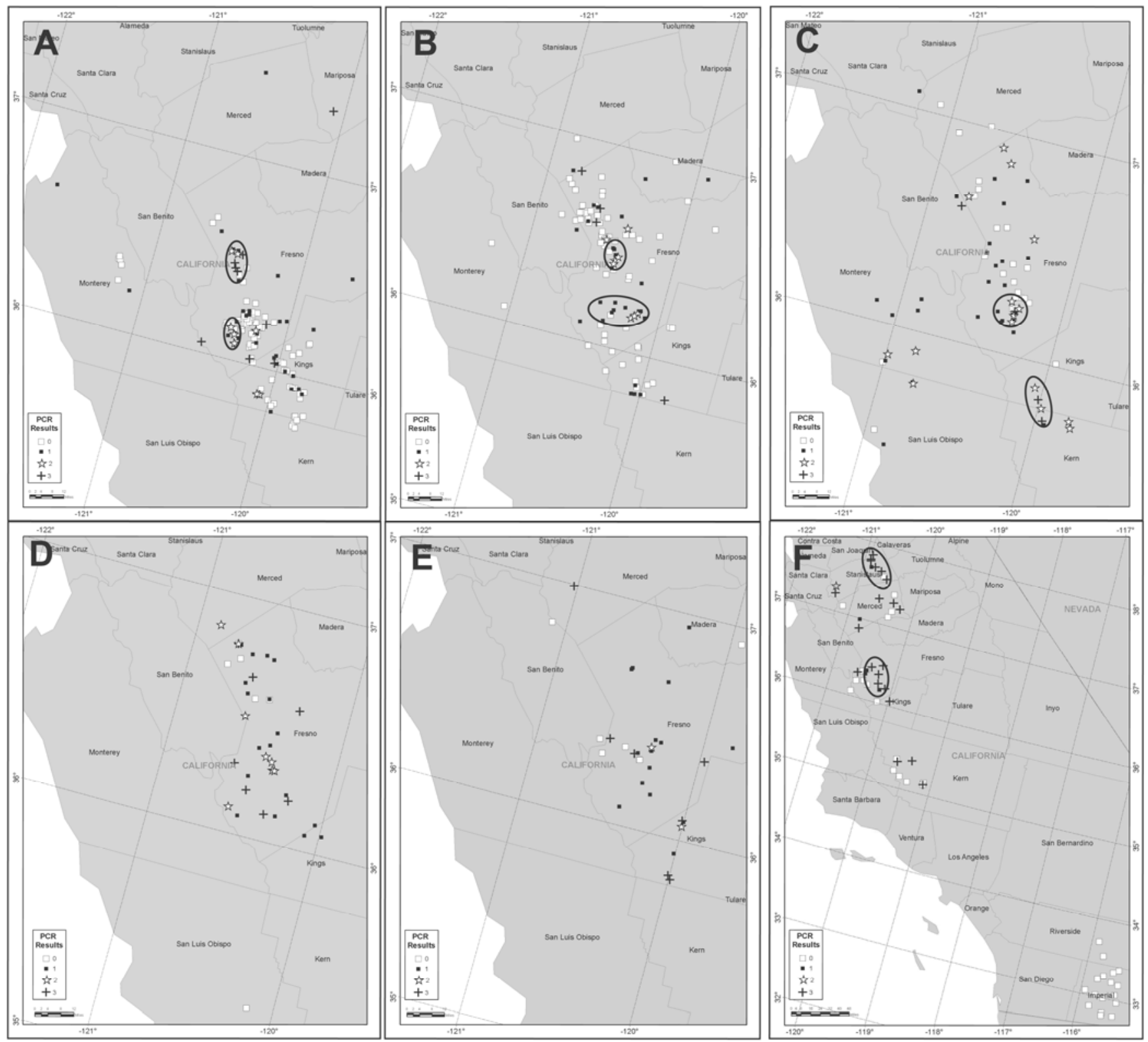

Fig. 4. Maps generated by Geographic Coordination System ArcGIS 9.2 showing locations where leafhoppers (Circulifer tenellus) were collected by Curly Top Virus Control Program personnel, and the results of curly top virus polymerase chain reaction (PCR) assays performed with these insects. Curly top virus detection is presented in terms of the relative intensities of curly top virus DNA fragments amplified by PCR from the insects as visualized in an ethidium bromide-stained gel. The following rating scale was used: $0=$ no curly top virus DNA fragment amplified; $1=$ weak intensity fragment; $2=$ medium intensity fragment; and 3 = strong intensity fragment. A to F represent results for leafhoppers collected in 2003 to 2008 , respectively. Circled areas indicate areas where leafhoppers with the greatest level of curly top virus were collected. 
hoppers were in western and southwestern Fresno County, whereas curly top virusnegative beet leafhoppers were detected in some areas of southern and northwestern Fresno County and northwestern Kings County (Fig. 4B). In 2005, beet leafhoppers were collected in Merced, Monterey, Fresno, and Kings counties. Curly top virus-positive beet leafhoppers were again clustered in southwestern Fresno County and western Kings County, as well as in southern Monterey County (Fig. 4C). Areas where curly top virus-negative beet leafhoppers were collected included northern and central Fresno County and parts of Merced County. In 2006, the beet leafhopper collections were mainly conducted along the western side of Fresno County, and curly top virus-positive beet leafhoppers were detected throughout western and southwestern Fresno County (Fig. 4D). Beet leafhoppers were mainly collected in Fresno County in 2007, and curly top viruspositive beet leafhoppers were again distributed in southwestern Fresno County and western Kings County (Fig. 4E). In 2008, beet leafhoppers were collected in Fresno, Imperial, Kern, Kings, Merced, Riverside, and Stanislaus counties. Curly top viruspositive beet leafhoppers with high viral titers were clustered in southwestern Fresno County and eastern Stanislaus County, with some curly top virus-positive beet leafhoppers also detected in western Kern and Kings counties (Fig. 4F). Curly top virus was not detected in beet leafhoppers collected from Imperial and Riverside counties. Taken together, these results revealed curly top virus hotspots in southwestern Fresno County and western Kings County.
Identification of potential reservoir hosts for viruliferous beet leafhoppers. To identify potential reservoir hosts for curly top viruses and beet leafhoppers, plant species from which beet leafhoppers were collected were recorded. Beet leafhoppers were collected from tomato plants and 14 species of weeds (Fig. 5). The most common hosts of the beet leafhoppers were redstem filaree (E. cicutarium (L.) L'Her), nettleleaf goosefoot (Chenopodium murale L.), perennial pepperweed, buckhorn plantain, Russian thistle, and Canada thistle (Cirsium arvense). The hosts from which curly top virus-positive beet leafhoppers were most commonly collected were London rocket, nettleleaf goosefoot, perennial pepperweed, Russian thistle, and fivehook bassia (Bassia hyssopifolia). In some cases, all beet leafhoppers collected from certain weeds were curly top virus positive; however, for many of these, the sample number was low (e.g., lambsquarter, mustards, pigweeds, and common purslane [Portulaca oleracea]). These results suggested that weed hosts of the beet leafhoppers may not necessarily be the main reservoir hosts for curly top viruses. However, filarees, nettleleaf goosefoot, perennial pepperweed, Russian thistle, and fivehook bassia appear to be good hosts for the beet leafhopper and curly top virus (based on being the source of a large number of curly top virus-positive beet leafhoppers).

\section{DISCUSSION}

In this study, we developed and applied PCR-based detection tools to (i) more rapidly and precisely identify plants with curly top in the field, (ii) identify the curly top virus species associated with curly top of tomatoes in the Central Valley of California, and (iii) evaluate whether monitoring of curly top virus in beet leafhoppers could be a predictor of curly top incidence in the field. Results of field surveys for incidence of curly top symptoms in tomato fields from 2002 to 2008 revealed that most fields had only trace or low incidences. Fields with medium to high incidences of curly top symptoms were found in Fresno County in 2002 and 2008 and in Kern County in 2003. These results are consistent with the sporadic and unpredictable nature of curly top disease, and demonstrate the need for a means to predict when severe outbreaks of the disease will occur.

In general, most of the samples $(\sim 80 \%)$ collected from plants with curly top symptoms during the surveys were confirmed to be infected with curly top virus based on results of the PCR test with the general curly top virus primer pair. However, samples from some plants with curly top symptoms collected during the surveys or provided by collaborators were negative for curly top virus infection when tested by PCR. Because the PCR test is reliable (few false negatives) and we have found no evidence of tomato-infecting curly top viruses that are not detected with this test, these negative samples most likely reflect other factors that cause curly top-like symptoms rather than false negative results. Factors that can induce such symptoms include initial symptoms of Tomato spotted wilt virus infection; belowground disorders; nutrient deficiencies, especially

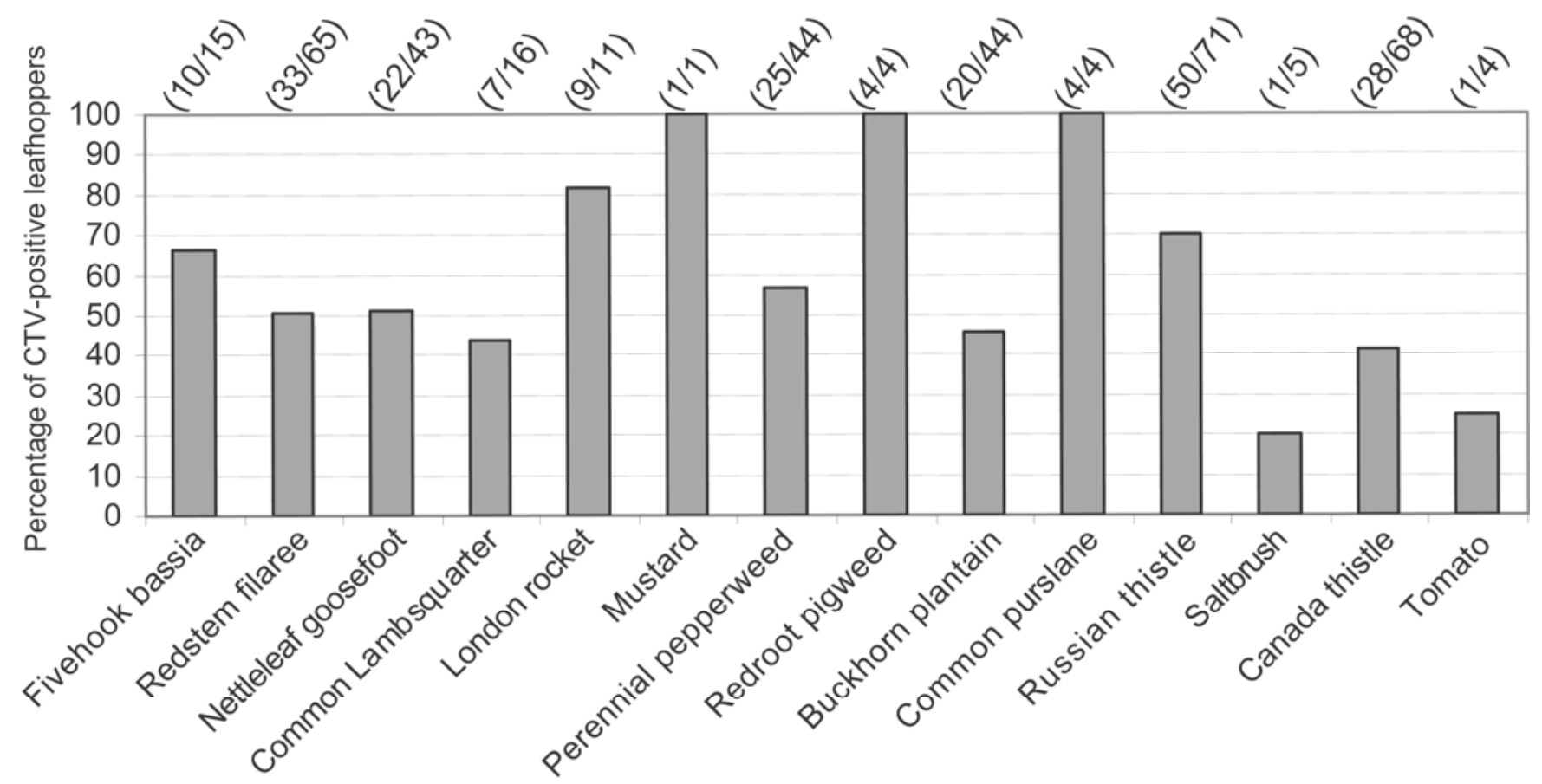

Fig. 5. Weed species from which leafhoppers were collected during the 2004 to 2008 growing seasons and percentage of curly top virus-positive leafhoppers collected from these weeds (as determined by polymerase chain reaction [PCR] with a general curly top virus primer pair). Numbers in parentheses represent the number of curly top virus-positive leafhopper samples out of the total number of samples tested. 
vein purpling associated with phosphorous deficiency; and other stresses, such as herbicide damage. Thus, this PCR-based assay will allow more accurate diagnosis of curly top disease in the field.

Before the development of molecular biology tools, it was not possible to assess the genetic diversity of viruses associated with curly top, and thus these viruses were collectively referred to as BCTV or curly top virus. The application of molecular tools, especially PCR and DNA sequencing, has revealed the presence of several distinct curtovirus species (21). This has also allowed for the detection and identification of curtoviruses associated with curly top in various crops in different geographical locations $(6,37,39)$. In the present study, we used these techniques to establish that BMCTV and BSCTV were the predominant curtoviruses associated with curly top of tomato in California. Overall, BMCTV was more commonly detected than BSCTV; however, BSCTV was more common in Fresno County, where it was also detected in sugar beet and pepper plants with curly top (Table 1). BCTV was not detected in tomato or other crops with curly top in California, which is in agreement with previous studies showing that BMCTV and BSCTV are the predominant species associated with curly top of sugar beet in the western United States (35,37-39). Interestingly, in a recent survey of curly top viruses associated with curly top of sugar beet, BCTV was detected at very low incidences in Idaho, Colorado, and Oregon; whereas it was not detected in California (39). The absence of BCTV in California could be due to reservoir or crop hosts favoring the selection and persistence of specific curly top virus species in different geographical areas.

PCR was an effective tool for monitoring curly top virus in beet leafhoppers. This approach provided insight into the epidemiology of curly top by allowing (i) correlation of curly top virus detection in beet leafhoppers with curly top incidence in tomato, (ii) identification of geographical areas with high populations of viruliferous beet leafhoppers, and (iii) identification of locations with potential curly top virus reservoir hosts. Our results indicated that beet leafhopper populations and the amount of curly top virus in beet leafhoppers (i.e., the proportion of beet leafhoppers with curly top virus and the viral titer) early in the season may be correlated with disease incidence in tomatoes in the field. Thus, in 2003, when there was a combination of high beet leafhopper populations having a high amount of curly top virus in February to March, a high incidence of curly top was observed in tomato fields in Kern County. In 2008, a high amount of curly top virus in beet leafhoppers collected in March and April was associated with higher incidences of curly top disease in surveyed tomato fields.
In contrast, in 2004 to 2007, low beet leafhopper populations with lower amounts of curly top virus early in the season were associated with lower incidences of curly top in tomato fields. This finding is also consistent with studies showing that higher rates of curly top virus infection are positively correlated with exposure of plants to higher numbers of viruliferous beet leafhoppers $(3,4,18,19,28)$, and that curly top virus titer in beet leafhoppers can influence disease development in certain hosts $(3,7,15)$. Thus, our results suggest that monitoring beet leafhopper populations and curly top virus incidence and titer in beet leafhoppers early in the season may be a predictor of disease development in the field. However, continued monitoring is needed to confirm this.

The curly top virus species identified in beet leafhoppers were similar to those detected in tomatoes with curly top. Thus, BMCTV was the predominant curly top virus species detected, although BSCTV also was commonly detected. In addition, BMCTV and BSCTV were detected together in some beet leafhopper samples; however, because these samples had multiple insects, it was not possible to determine whether individual insects carried both viruses (Fig. 3). We also consistently observed that BSCTV titers in beet leafhoppers were higher than those of BMCTV (data not shown). Taken together with the finding that BSCTV was associated with curly top of sugar beet and pepper, these results may reflect differences in viral titers in acquisition hosts (7) or in the virus-vector interaction. Interestingly, BCTV was detected in beet leafhoppers collected in late fall of 2004 and spring of 2007, which indicates that BCTV may be present in reservoir hosts in the foothills of the Central Valley. However, the infrequent detection and low viral titer of BCTV in beet leafhoppers is in agreement with this curtovirus not playing a major role in curly top in California.

Knowing where leafhoppers carrying high levels of curly top virus occur could improve disease management by allowing for targeted spraying of viruliferous beet leafhoppers. Six major beet leafhopper breeding areas in the western United States were identified in the 1950s, including the San Joaquin Valley of California $(3,12)$. However, it was not determined to what extent beet leafhoppers in these areas actually carried curly top virus. In the present study, beet leafhoppers were collected mainly from Fresno and Kings counties, but also from Imperial, Kern, Merced, Monterey, Riverside, and Stanislaus counties. Areas with high proportions of curly top virus-positive beet leafhoppers and high viral titers included western parts of Fresno and Kings counties (Fig. 4), whereas no curly top virus was detected in beet leafhoppers collected in Imperial and Riverside counties. These results suggest that hotspots of curly top virus-positive beet leafhoppers can be identified, which could be targeted for insecticide application. Furthermore, these hotspot areas may reveal concentrations of curly top virus reservoir hosts.

By identifying plant hosts from which beet leafhoppers were collected and correlating this with results of curly top virus detection in beet leafhoppers, potential reservoir hosts of curly top virus were identified (e.g., London rocket, Russian thistle, bassia, and peppergrass; Fig. 5). These findings are consistent with previous studies indicating that these weeds are curly top virus reservoirs $(3,9,10)$. Our results also support the notion that Russian thistle may be an important summer reservoir host during the growing season in the agricultural valleys (3). Moreover, based on the numbers of beet leafhoppers collected and results of PCR detection of curly top virus in beet leafhoppers, there were differences in the capacity of some hosts to serve as reservoirs for beet leafhoppers versus curly top virus (Fig. 5). Hosts of both the beet leafhopper and curly top virus, such as Russian thistle, could be eliminated as part of a curly top management strategy.

The beet leafhopper undergoes several generations (five or more depending on the environmental conditions) in the Central Valley before migrating back to the foothills in the late fall. The finding that curly top virus was consistently detected in beet leafhoppers collected in the Central Valley during the summer and fall, together within the fact that the virus is not transovarially transmitted $(3,31)$, indicates that weeds or crops are serving as curly top virus reservoirs. This allows for beet leafhoppers to acquire the virus throughout the growing season. Additional evidence for this comes from the consistent observation of BMCTV and BSCTV infections in lateplanted fresh market tomatoes in Merced County. Thus, our findings are in agreement with results of previous studies of Bennett (3) and Creamer et al. (9), indicating that curly top virus inoculum sources must exist in the agricultural areas in the Central Valley.

In summary, the development and application of PCR-based detection assays provided new insight into curly top of tomato in California. These assays can now be used to precisely diagnose curly top virus infections in the field, and to identify the curtovirus species associated with curly top in various crops and geographical locations. BMCTV is the most prevalent and widespread curly top virus associated with curly top of tomato, but BSCTV also plays an important role. Thus, these curtoviruses should be used for screening tomato germplasm for curly top resistance and for engineering tomato for curly top virus resistance. The PCR assay for detecting curly top virus in beet leafhoppers revealed in- 
sight into when and where the insects are carrying curly top virus and potential reservoir hosts of the beet leafhoppers and curly top virus. This method may be useful as a predictor for curly top outbreaks in the field.

\section{ACKNOWLEDGMENTS}

This research was supported in part by grants from the California Department of Food and Agriculture as part of the Specialty Crops Research Program, the California Tomato Commission, and the California Tomato Research Institute. We thank Steve Koike, Jim Ledford, and Gene Miyao for assistance in conducting disease surveys and for providing samples.

\section{LITERATURE CITED}

1. Arif, M., Hassan, S., and Shafiq, M. 1991. Incidence and distribution of viruses infecting sugar beet crop in North West Frontier Province, Pakistan. Sarhad J. Agric. 7:665-673.

2. Baliji, S., Black, M. C., French, R., Stenger, D. C., and Sunter, G. 2004. Spinach curly top virus: A newly described Curtovirus species from southwest Texas with incongruent gene phylogenies. Phytopathology 94:772-779.

3. Bennett, C. W. 1971. The Curly Top Disease of Sugarbeet and Other Plants. American Phytopathological Society, St. Paul, MN.

4. Bennett, C. W., and Wallace, H. E. 1938. Relation of the curly top virus to the vector, Eutettix tenellus. J. Agric. Res. 56:31-52.

5. Briddon, R. W., Stenger, D. C., Bedford, I. D., Stanley, J., Izadpanah, K., and Markham, P. G. 1998. Comparison of a beet curly top virus isolate originating from the old world with those from the new world. Eur. J. Plant Pathol. 104:77-84.

6. Chen, L.-F., and Gilbertson, R. L. 2008. Beet mild curly top virus. Pages 195-215 in: Characterization, Diagnosis \& Management of Plant Viruses. G. P. Rao, S. M. Paul Khurana, and S. Lenardon, ed. Studium Press LLC, Houston, TX, USA.

7. Chen, L.-F., and Gilbertson, R. L. 2009. Curtovirus-cucurbit interaction: Acquisition host plays a role in leafhopper transmission in a host-dependent manner. Phytopathology 99:101-108.

8. Chen, L.-F., Soto-Aguilar, M. J., and Gilbertson, R. L. 2004. Application of PCRbased detection methods for monitoring curly top viruses in beet leafhoppers and tomato plants in California. (Abstr.) Phytopathology 94:S17.

9. Creamer, R., Luque-Williams, M., and Howo, M. 1996. Epidemiology and incidence of beet curly top geminivirus in naturally infected weed hosts. Plant Dis. 80:533-535.

10. Davis, M. R., Wang, H., Falk, B. W., and Nunez, J. J. 1998. Curly top virus found in perennial shrubs in foothills. Calif. Agric.
52:38-40.

11. Dellaporta, S. L., Wood, J., and Hicks, J. B. 1983. A plant DNA minipreparation: Version II. Plant Mol. Biol. Rep. 1:19-21.

12. Douglass, J. R., and Cook, W. C. 1954. The beet leafhopper. U.S. Dep. Agric. Circ. 942:21.

13. Esau, K. 1976. Hyperplastic phloem and its plastids in spinach infected with the curly top virus. Ann. Bot. 40:637-644.

14. Fauquet, C. M., and Stanley, J. 2005. Revising the way we conceive and name viruses below the species level: A review of geminivirus taxonomy calls for new standardized isolate descriptors. Arch. Virol. 150:2151-2179.

15. Giddings, N. J. 1946. Mass action as a factor in curly-top-virus infection of sugar beet. Phytopathology 36:53-56.

16. Guzmán, P., Goldberg, N., Liddell, C. M., and Gilbertson, R. L. 1996. Detection and partial characterization of beet curly top geminivirus (BCTV) isolates infecting beans, peppers and tomatoes in California and New Mexico. Annu. Rep. Bean Improv. Coop. 39:75-76.

17. Hallock, H. C., and Douglass, J. R. 1956. Studies of four summer hosts of the beet leafhopper. J. Econ. Entomol. 49:388-391.

18. Hills, O. A. 1958. Effect of curly top-infective beet leafhoppers on watermelon plants in different stages of development. J. Econ. Entomol. 51:434-436.

19. Hills, O. A., and Taylor, E. A. 1949. Effect of curly top infective leafhoppers on cantaloup plants. J. Econ. Entomol. 42:897-900.

20. Klute, K. A., Nadler, S. A., and Stenger, D. C. 1996. Horseradish curly top virus is a distinct subgroup II geminivirus species with rep and C4 genes derived from a subgroup III ancestor. J. Gen. Virol. 77:1369-1378.

21. Lam, N., Creamer, R., Rascon, J., and Belfon, R. 2009. Characterization of a new curtovirus, pepper yellow dwarf virus, from chile pepper and distribution in weed hosts in New Mexico. Arch. Virol. 154:429-436.

22. Larsen, R. C., and Miklas, P. N. 2004. Generation and molecular mapping of a sequence characterized amplified region marker linked with the Bct gene for resistance to Beet curly top virus in common bean. Phytopathology 94:320-325.

23. Lawson, F. R., Chamberlin, J. C., and York, G. T. 1951. Dissemination of the beet leafhopper in California. U.S. Dep. Agric. Tech. Bull. 59.

24. Rojas, M. R., Gilbertson, R. L., Russell, D. R., and Maxwell, D. P. 1993. Use of degenerate primers in the polymerase chain reaction to detect whitefly-transmitted geminiviruses. Plant Dis. 77:340-347.

25. Rojas, M. R., Hagen, C., Lucas, W. J., and Gilbertson, R. L. 2005. Exploiting chinks in the plant's armor: Evolution and emergence of geminiviruses. Annu. Rev. Phytopathol. 43:361-394.

26. Rybicki, E. P. 1994. A phylogenetic and evolu- tionary justification for three genera of Geminiviridae. Arch. Virol. 139:49-77.

27. Salati, R., Nahkla, M. K., Rojas, M. R., Guzman, P., Jaquez, J., Maxwell, D. P., and Gilbertson, R. L. 2002. Tomato yellow leaf curl virus in the Dominican Republic: Characterization of an infectious clone, virus monitoring in whiteflies, and identification of reservoir hosts. Phytopathology 92:487-496.

28. Severin, H. H. P. 1931. Modes of curly-top transmission by the beet leafhopper, Eutettix tenellus (Baker). Hilgardia 6:253-275.

29. Severin, H. H. P. 1933. Field observations on the beet leafhopper, Eutettix tenellus, in California. Hilgardia 7:282-350.

30. Severin, H. H. P. 1934. Weed host range and overwintering of curly-top virus. Hilgardia 8:263-277.

31. Soto, M. J., and Gilbertson, R. L. 2003. Distribution and rate of movement of the curtovirus Beet mild curly top virus (family Geminiviridae) in the beet leafhopper. Phytopathology 93:478-484.

32. Stahl, C. F. 1920. Studies on the life history and habits of the beet leafhopper. J. Agric. Res. 4:245-252.

33. Stanley, J., Markham, P. G., Callis, R. J., and Pinner, M. S. 1986. The nucleotide sequence of an infectious clone of the geminivirus beet curly top virus. EMBO J. 5:1761-1767.

34. Stenger, D. C. 1994. Complete nucleotide sequence of the hypervirulent $\mathrm{CFH}$ strain of beet curly top virus. Mol. Plant-Microbe Interact. 7:154-157.

35. Stenger, D. C. 1995. Genotypic variability and the occurrence of less than genome-length viral DNA forms in a field population of beet curly top geminivirus. Phytopathology 85:1316-1322.

36. Stenger, D. C., Carbonaro, D., and Duffus, J. E. 1990. Genomic characterization of phenotypic variants of beet curly top virus. J. Gen. Virol. 71:2211-2215.

37. Stenger, D. C., and McMahon, C. L. 1997 Genotypic diversity of beet curly top virus populations in the western United States. Phytopathology 87:737-744.

38. Stenger, D. C., and Ostrow, K. M. 1996. Genetic complexity of a beet curly top virus population used to assess sugar beet cultivar response to infection. Phytopathology 86:929-933.

39. Strausbaugh, C. A., Wintermantel, W. M., Gillen, A. M., and Eujayl, I. A. 2008. Curly top survey in the Western United States. Phytopathology 98:1212-1217.

40. Wintermantel, W. M., and Kaffka, S. R. 2006. Sugar beet performance with curly top is related to virus accumulation and age at infection. Plant Dis. 90:657-662.

41. Wisler, G. C., and Duffus, J. E. 2000. A century of plant virus management in the Salinas Valley of California, 'East of Eden'. Virus Res. 71:161-169. 